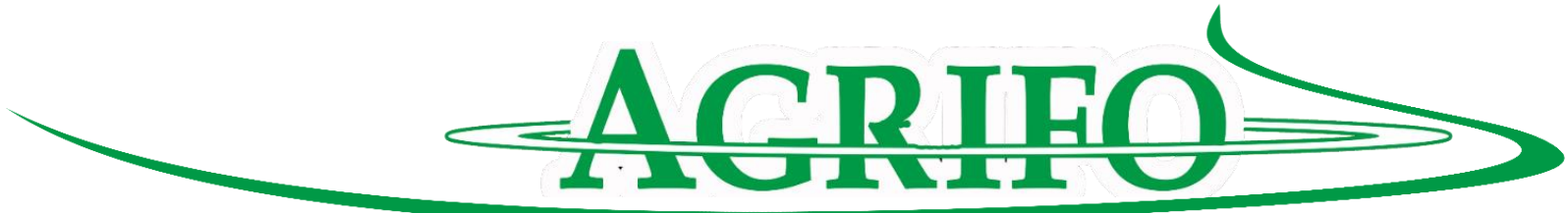

\title{
ANALISIS BAURAN PEMASARAN TEH HERBAL ASAM GELUGUR (GARCIE TEA) PADA KOMUNITAS LOKAL BIOVERSITY DI KABUPATEN SIJUNJUNG
}

\author{
Rani Rahmi Yanti ${ }^{1}$, dan Noni Novarista ${ }^{2}$ \\ email: noninovarista@gmail.com
}

\begin{abstract}
ABSTRAK
Penelitian ini bertujuan untuk mengetahui : (1) bauran pemasaran teh herbal asam gelugur pada Komunitas Lokal Bioversity (2) kendala apa saja yang dihadapi oleh Komunitas Lokal Bioversity dalam memasarkan teh herbal asam gelugur. Penelitian ini dilakukan di Nagari Latang Kecamatan Lubuk Tarok Kabupaten Sijunjung pada Komunitas Lokal Bioversity yang telah dilakukan pada bulan Mei-Desember 2016. Metode penelitian yang digunakan adalah metode studi kasus. Data yang digunakan terdiri atas data primer dan data sekunder. Data primer diperoleh secara langsung dari responden berupa hasil pengamatan langsung perolehan dokumen dan wawancara langsung. Data sekunder merupakan data tidak langsung yang diperoleh dari dokumendokumen. Metode analisis yang digunakan dalam penelitian ini adalah deskriptif kualitatif. Hasil yang diperoleh dari penelitian ini: 1) bauran produk yang ada di Komunitas Lokal Bioversity meliputi kualitas, desain, merek dan ukuran 2) bauran harga meliputi penetapan harga, potongan harga dan sistem pembayaran 3) bauran distribusi meliputi saluran pemasaran dan lokasi 4) bauran promosi meliputi pameran dagang, dan iklan. Kendala yang dihadapi dilihat pada segi internal dan eksternal, pada segi internal dilihat dari segi produk, harga, distribusi, dan promosi. Sedangkan untuk segi eksternal dilihat dari keberadaan pesaing.
\end{abstract}

Kata kunci : Bauran Pemasaran, Teh Herbal, Asam Gelugur

\section{PENDAHULUAN}

Salah satu peluang besar bagi
pengembangan industri yakni
pengembangan produk herbal, seperti
teh herbal. Teh herbal adalah sebutan
untuk ramuan bunga, daun, biji, akar,
atau buah kering untuk membuat
minuman yang juga disebut teh herbal.
Walaupun disebut "teh", ramuan atau
minuman ini tidak mengandung daun
dari tanaman teh (Camellia sinensis).
Perubahan ilmu dan pengetahuan serta
teknologi kelihatannya memberikan efek
yang cukup penting pada inovasi produk

teh. Sebagian pihak mulai meningkatkan teh dengan varian serta bahan baku yang bermacam. Tak terus-menerus memiliki bahan baku teh, karena pada saat ini terlihat beragam varian teh herbal dimana bahan baku yang dipakai malah tak memiliki kandungan teh. Adapun yang digunakan yaitu ramuan rempahrempah seperti bunga, daun, buah kering serta akar.

Salah satu kelompok wanita tani (KWT) yang memproduksi teh herbal di Kabupaten Sijunjung yaitu Komunitas Lokal Bioversity yang berlokasi di

\footnotetext{
${ }^{1}$ Sekolah Tinggi Ilmu Pertanian (STIPER) Sijunjung Sumatera Barat

${ }^{2}$ Sekolah Tinggi Ilmu Pertanian (STIPER) Sijunjung Sumatera Barat
} 
Nagari Latang Kecamatan Lubuk Tarok Kabupaten Sijunjung Provinsi Sumatera Barat, yang ditumbuh kembangkan oleh Dinas Tanaman Pangan dan Perkebunan Kabupaten Sijunjung, Balitbu Tropika dan Puslitbang Hortikultura Deptan. KWT di Komunitas Lokal Bioversity sebuah kelembagaan yang lahir dari keinginan masyarakat untuk mewadahi peran serta mereka dalam proses konservasi dan pemanfaatan kerabat manggis, telah menghasilkan produk teh asam gelur (garci tea). Teh herbal asam gelugur adalah teh herbal yang bahan bakunya daun asam gelugur $90 \%$ dan buah asam gelugur 10\% diolah secara alami tanpa bahan pengawet, dan berkhasiat: menyerap kelebihan lemak (melangsingkan/menurunkan berat badan), mengurangi kolesterol, melebarkan pembuludarah memperbaiki sirkulasi darah, menurunkan tekanan darah tinggi.

Pemasaran merupakan salah satu faktor penting untuk mencapai sukses bagi perusahaan. Perusahaan dengan penjualan yang banyak pasti memiliki pemasaran yang hebat dan terencana. Pemasaran juga merupakan faktor penting dalam memenuhi kebutuhan pembeli yang ada maupun pembeli potensional, untuk itu kegiatan pemasaran harus memberi kepuasaan kepada konsumen. Perusahaan dalam memenuhi keinginan dan kebutuhan konsumen harus menyusun kebijakan produk, harga, prmosi, dan distribusi yang tepat, sesuai dengan konsumen sasaranya. Harga dari teh herbal asam gelugur ini pada saat ini yaitu Rp 40.000 per kotak. Isi satu kotaknya sebayak 30 sachet. Pemasaran teh herbal asam gelugur ini sudah sampai ke Sumatera, Jawa, Bali bahkan sudah ada permintaan untuk memenuhi pangsa pasar Malaysia dan Belanda.
Menurut Kotler (2002), pemasaran merupakan hal yang paling penting dilaksanakan oleh perusahaan dalam usahanya menciptakan pasar untuk memperoleh kesempatan mendapatkan laba yang optimal dan menjaga kelangsungan hidup suatu usaha. Salah satu usaha dalam bidang apapun memerlukan dukungan konsep pemasaran berupa bauran pemasaran (marketing mix) yakni mencakup produk, harga, promosi dan distribusi. Untuk mencapai tujuan pemasaran, maka keempat unsur tersebut harus saling mendukung antara satu dengan yang lainnya. Tidak bisa hanya satu komponen saja yang diprioritaskan, sebab apabila perusahaan ingin memenuhi kebutuhan secara memuaskan maka harus didukung oleh keempat unsur diatas. Berdasarkan paparan diatas penulis tertarik untuk meneliti permasalahan yang ada dalam perusahaan mengenai penerapan bauran pemasaran untuk teh herbal asam gelugur.

\section{METODOLOGI PENELITIAN}

Penelitian ini dilakukan di Nagari Latang Kecamatan Lubuk Tarok Kabupaten Sijunjung pada Komunitas Lokal Bioversity. Pemilihan lokasi penelitian dilakukan secara sengaja (purposive) dengan pertimbangan Komunitas Lokal Bioversity satu satunya KWT yang memproduksi teh herbal asam gelugur (garci tea) di Kabupaten Sijunjung yang memproduksi teh herbal yang berbahan baku asam gelugur. Metode penelitian yang digunakan adalah metode studi kasus. Data yang digunakan terdiri atas data primer dan data sekunder. Data primer diperoleh secara langsung dari responden berupa hasil pengamatan langsung perolehan dokumen dan wawancara langsung. Data sekunder merupakan data tidak langsung yang 
diperoleh dari dokumen-dokumen. Metode analisis yang digunakan dalam penelitian ini adalah deskriptif kualitatif. Variabel penelitian adalah: 1) 4P yaitu produk (kualitas, desain, merek dan ukuran), harga (penetapan harga jual, potongan harga jual dan sistem pembayaran), distribusi (saluran pemasaran dan lokasi), dan promosi, 2) kendala internal dan eksternal.
HASIL DAN PEMBAHASAN

\subsection{Bauran Pemasaran Teh Herbal Asam Gelugur}

Bauran pemasaran adalah semua faktor yang dapat dikuasai oleh seseorang manajer pemasaran dalam rangka mempengaruhi permintaan konsumen terhadap barang dan jasa.

Tabel 5. Data Penjualan Teh Herbal Asam Gelugur mulai pada Bulan Maret 2015Februari 2016.

\begin{tabular}{|c|c|c|}
\hline No & Bulan & Penjualan (Kotak) \\
\hline 1 & Maret & 778 \\
\hline 2 & April & 593 \\
\hline 3 & Mei & 963 \\
\hline 4 & Juni & 620 \\
\hline 5 & Juli & 570 \\
\hline 6 & Agustus & 580 \\
\hline 7 & September & 655 \\
\hline 8 & Oktober & 446 \\
\hline 9 & November & 590 \\
\hline 10 & Desember & 212 \\
\hline 11 & Januari & 303 \\
\hline 12 & Februari & 833 \\
\hline & Jumlah & 7143 \\
\hline
\end{tabular}

Sumber: Komunitas Lokal Bioversity Nagari Latang

Dari Tabel 5 di atas dapat dilihat bahwa penjualan teh herbal asam gelugur pada bulan maret 2015-maret 2016 mengalami fluktuasi. Penjualan terendah terjadi pada bula april 2015 dan penjualan tertinggi terjadi pada bulan maret 2016.

Komunitas Lokal Bioversity sebagai salah satu produsen teh herbal harus memiliki strategi bauran pemasaran yang tepat agar produknya lebih dikenal luas oleh masyarakat. Strategi bauran pemasaran yang dijalani oleh Komunitas Lokal Bioversity dapat dijabarkan menurut konsep bauran pemasaran. Menurut Kotler (2012;25) konsep bauran pemasran meliputi unsur produk (product), harga(price), distribusi(place), dan promosi (promotion).

\subsubsection{Produk}

Produk adalah sesuatu yang ditawarkan pada pasar baik produk nyata ataupun produk tidak nyata (jasa) sehingga dapat memuaskan keinginan dan kebutuhan pasar.

Bauran produk teh herbal asam gelugur yang terdapat pada Kominitas Lokal Bioversity adalah sebagai berikut.

a. Kualitas produk

Komunitas Lokal Bioversity berusaha untuk menjaga kualitas produk 
teh herbal asam gelugur yang dipasarkan agar tetap terjamin kualitasnya. Kualitas produk teh herbal asam gelugur yang dipasarkan tidak dibedakan berdasarkan kriteria tertentu.

Untuk mengawasi mutu produk teh herbal asam gelugur yang dipasarakan agar kualitasnya terjaga maka dilakukan penyortiran bahan baku yang akan digunakan seperti daun dan buah asam gelugur. Produk teh herbal asam gelugur ini menggunakan 90\% daun asam gelugur dan $10 \%$ buah asam gelugur yang telah dikeringkan selain itu produk ini tidak menggunakan bahan pengawet sehingga aman untuk dikonsumsi. Untuk meyakinkan konsumen bahwa produk ini benar-benar aman Komunitas Lokal Bioversity telah mendapatkan label halal setelah tiga bulan produksi. Teh herbal asam gelugur ini memiliki masa exspayear selama 1 tahun.

Teh herbal asam gelugur ini mengandung (-)-hydroxy-citric acid (HCA) yang dapat menghambat yang dapat menghambat ATP dependent citratelyase, enzim kunci dalam mengubah karbohidrat menjadi asam lemak dan sintesis cholesterol. Teh herbal asam gelugur ini berkhasiat menyerap kelebihan lemak (melangsingkan/ menurunkan berat badan) mengurangi kolesterol melebarkan pembuluh darah, memperbaiki sirkulasi darah menurunkan tekanan darah tinggi menurut para ahli yang telah meneliti asam gelugur di Nagari Latang tersebut . Hal ini sesuai dengan pendapat Kotler (2006: 299) kualitas produk adalah kemampuan produk untuk menampilkan fungsinya, hal ini termasuk waktu kegunaan dari produk.

\section{b. Desain}

Cara lain untuk menambahkan kesan suatu produk adalah melalui desain produk. Beberapa perusahaan mempunyai reputasi yang sangat baik karena desain produknya yang benarbenar bagus. Desain produk memiliki fungsi penting bagi produk yang akan dipasarakan, dengan desain yang menarik dan sesuai akan membuat produk memiliki nilai jual yang lebih tinggi dari pada dikemas seadanya. Menurut Stanto (1991: 285) desain produk yang baik dapat meningkatkan pemasaran produk.

Desain produk teh herbal asam gelugur didesain oleh Litbang. Desain produk teh herbal ini cukup menarik dan sangat menggambarkan produk tersebut. Seperti kotak yang berwarna hijau dengan gambar cangkir yang berisi teh disamping cangkir ada buah asam gelugur dan daun asam gelugur, selain itu juga ada gambar rumah adat dari Sumatera Barat yaitu rumah gadang. Menurut keterangan dari Komunitas Lokal Boiversity arti dari desain produk tersebut yaitu seperti cangkir yang berisi teh yang berarti menandakan produk ini adalah produk teh. Untuk gambar buah dan daun asam gelugur ini menurut Komunitas Lokal Bioversity mengartikan bahwa bahan baku dari produk ini adalah buah dan daun asam gelugur. Selanjutnya gambar rumah adat Sumatera Barat yaitu rumah gadang menurut Komunitas Lokal Bioversity gambar tersebut menunjukan bahwa produk ini berasal dari Sumatera Barat.

\section{c. Merek}

Pemberian merek merupakan masalah pokok dalam starategi produk. Nama merek yang baik dapat menembahkan keberhasilan yang besar pada produk. Komunitas Lokal 
Bioversity menggunakan nama "Garci Tea" untuk merek produk teh herbal asam gelugur yang mereka produksi. Garci sendiri diambil dari bahasa latin asam gelugur yaitu Garcinia atrovirdis Griff. Sedangkan Tea yaitu bahasa Inggris teh.

Menurut Kotler (2008) ada lima kriteria untik memilih elemen merek diantaranya dapat diingat, berarti, dapat disukai, dapat ditransfer, dapat dilindungi

Dari hasil penelitian Komunitas Lokal Bioversity merek yang digunakan telah memenuhi ke lima elemen tersebut. Seperti yang pertama mudah diingat, merek pada produk teh herbal asam gelugur ini cukup mudah diingat dikarenakan merek pada produk ini hanya terdiri dari 2 kata saja yaitu Garci dan Tea, garci yang merupakan bahasa latin dari bahan baku yang didunakan yaitu asam gelugur. Kedua, berarti yaitu merek dari produk teh herbal asam gelugur ini telah menggambarkan bahwa produk ini merupakan produk yang tergolong ke kategori produk minuman yaitu dari kata Tea. Ketiga, dapat disukai maksudnya merek produk teh yang di produksi oleh Komunitas Lokal Bioversity ini cukup menarik kerena merek ini mengunakan bahasa latin dari bahan baku yang digunakan karena jarang produk yang menggunakan bahas latin dari bahan bakunya. Keempat, dapat ditrasfer maksudnya disini apakah merek pada produk teh ini dapat diterjemahkan kebahasa lain, merek produk pada teh herbal asam gelugur ini bisa diartikan ke bahasa lain. Kelima dilindungi, merek pada teh herbal ini dapat dilindungi karena Komunitas Lokal Bioversity telah memiliki izin usaha.

\section{d. Ukuran}

Ukuran suatu produk mempunyai hubungan yang erat dengan kebiasaan pembeli jumlah kebutuhan konsumen. Ini berarti kebutuhan konsumen yang satu dengan yang lainnya berbeda-beda, sehinga perlu menyediakan produk dengan berbagai macam ukuran. Hal ini bertujuan agar konsumen dapat menyesuaikan antara kebutuhannya dengan ukuran produk yang ada.

Namun pada Komunitas Lokal Bioversity baru hanya memproduksi satu ukuran yang dikemas menggunakan kotak. Sebelum dikemas menggunakan kotak teh herbal asam gelugur ini awalnya dikemas menggunakan toples yang berisi 50 sachet kemudian diganti kemasannya mengunakan alumunium foil dikarenakan kemasan yang menggunakan toples gampang terbuka sehingga membuat produk tidak terjaga kualitasnya. Pada kemasan yang menggunakan alumunium foil berisi 30 sachet. Kemudian kemasan disempurnakan lagi menggunakan kotak, ukuran kotak tersebut adalah $14 \mathrm{~cm} \times 5 \mathrm{~cm}$ dengan tinggi kotak $6 \mathrm{~cm}$. Jadi setelah teh dimasukan kedalam alumunium foil sebanyak 30 sachet kemudian baru dimasukan kedalam kotak, setelah itu kotak dibungkus kembali dengan plastik bening dan direkat, sehingga produk benar-benar terjaga.

\subsubsection{Harga}

unsur Harga merupakan satu-satunya memberikan pemasukan dan pendapatan, sedangkan ketiga unsur lainnya (produk, harga, distribusi, promosi) timbulnya biaya (pengeluaran). Disamping itu harga merupakan unsur bauran pemasaran yang bersifat fleksibel artinya dapat diubah dengan cepat. 
Menurut Kotler (2001:195). Harga adalah nilai yang dipertukarkan konsumen untuk suatu manfaat atas pengkonsumsian, penggunaan atau kepemilikan barang atau jasa. Harga teh herbal yang diproduksi Komunitas Lokal Bioversity ini adalah sebesar Rp 40.000 perkotak dengan isi 30 sachet.

a. Penetapan harga

Dalam penetapan harga Komunitas Lokal Bioversity memperhitungkan biaya produksi, dimana biaya produksi ini memiliki beberapa komponen yang meliputi biaya bahan baku, biaya pegawai, biaya bahan bakar dan lisrik, biaya pemasaran dan lain-lain. Penetapan harga tersebut termasuk kedalam penetapan harga biaya (plus cost-plus princing method) yang dihitung dengan cara menjumlahkan biaya total perunit dengan marjin sehingga didapatkan harga jual perunit. Merjin yang digunakan berupa keuntungan dan pajak.

Komunitas Lokal Bioversity menetapkan harga jual ke distributor dengan cara menembahkan HPP dengan keuntungan dan pajak. Dalam hal ini perusahaan menetapkan harga yang berbeda untuk setiap segmen konsumen. Untuk harga jual keriseler Komunitas Lokal Bioversity menetapkan harga Rp35.000 per kotak sedangakan harga jual untuk konsumen adalah Rp40.000 perkotak. Agar lebih jelasnya dapat dilihat pada Tabel 6 sebagai berikut:

Tabel 6. Penentuan Biaya Produksi per kotak Teh Herbal Asam Gelugur

\begin{tabular}{lll}
\hline No & Biaya-biaya & Harga $(\mathbf{R p})$ \\
\hline 1 & Biaya bahan baku & $1.815,82$ \\
\hline 2 & Biaya gaji karyawan & $6.156,38$ \\
\hline 3 & Biaya bahan bakar & 0,05 \\
\hline 4 & Biaya listrik & 157,65 \\
\hline 5 & Biaya pemasaran & 179,20 \\
\hline 6 & Biaya pendukung & $1.274,25$ \\
\hline 7 & Biaya laian-lain & 441,27 \\
\hline 8 & Biaya penyusutan peralatan & 402,09 \\
\hline & Total biaya & $10.426,71$ \\
\hline
\end{tabular}

Harga jual setelah laba 30\% dari biaya total:

Harga per kotak herbal asam gelugur $=$ Jumlah total biaya produksi + Laba

$$
\begin{aligned}
& =\operatorname{RP} 10.426,71+(30 \% \times \operatorname{Rp} 10.426,71) \\
& =\operatorname{Rp} 10.426,71+(\operatorname{Rp} 3.128,013) \\
& =\operatorname{Rp} 13.554,723
\end{aligned}
$$

Biaya produksi pada Komunitas Lokal Bioversity per kotak adalah sebesar Rp10.426,71dengan laba $30 \%$ yaitu sebesar Rp 3.128,013jadi biaya produksi dan laba pada Komunitas Lokal Bioversity yang dihasilkan adalah sebesar Rp13.554,723. Maka harga yang ditetapkan oleh Komunitas Lokal Bioversity tergolong mahal.
b.Potongan harga

Potongan harga merupakan pengurangan harga yang diberikan oleh penjual kepada pembeli sebagai penghargaan atas aktivitas tertentu dari pembeli yang menyenangkan padi penjual. 
Potongan harga digunakan untuk meningkatkan jumlah penjualan dan hasil penerimaan penjualan. Komunitas Lokal Bioversity memberikan potongan harga kepada konsumen yang membeli dalam jumlah besar minimal 50 kotak yaitu $12 \%$ atau setara $\mathrm{Rp} 4.800$ dan dibulatkan menjadi Rp 5.000 sama dengan Rp 35.000 per kotak dari harga normal pembeli tersebut biasanya dilakukan oleh reseler yang akan menjual kembali produk tersebut.

\section{c. Sistem pembayaran}

Sistem pembayaran yang dilakukan yang diterapkan di Komunitas Lokal Bioversity ada 2 macam yaitu pembayaran tunai dan pembayaran kredit.

\section{Sistem pembayaran tunai}

Sisitem ini merupakan yang mudah dan dapat diterapkan untuk semua segmen konsumen. Sistem pembayaran tunai umumnya dilakukan jika konsumen membeli langsung ke produsen. Cara ini dilakukan karena umumnya konsumen membeli dalam jumlah yang relatif sedikit.

\section{Sistem pembayaran kredit}

Pembayaran dengan sistem kredit untuk pembelian yang rutin yang dilakukan oleh pedagang pengecer (reseler). Pembayaran dapat dilakukan pada awal pembelian dengan membayar dimuka dan setelah itu bisa dibayar kembali 1 atau 2 bulan kemudian dilunasi secara keseluruhan. Pada sistem pembayaran kredit ini tergadang juga menimbulkan masalah seperti pedagang pengecer atau (reseler) yang tidak tepat waktu dalam pembayaran, sehingga tidak sesuai dengan waktu yang telah disepakati karena para pedagang pengecer (reseler) terkadang membayar setelah produk habis terjual.

\subsubsection{Distribusi}

Untuk memperlancar arus barang dan jasa dari produsen ke konsumen, salah satu faktor yang penting adalah memilih saluran secara tepat saluran pemasaran yang dipergunakan untuk menyampaikan barang dan jasa dari produsen ke konsumen. Menurut Swastha (2008:285) saluran distribusi merupakan suatu struktur organisasi dalam perusahaan dan luar perusahaan yang terdiri dari agen, pedagang besar, pengecer, melalui sebuah komoditi produk atau jasa dipasarkan.

\section{a. Saluran pemasaran}

Saluran pemasaran teh herbal asam gelugur dilakukan melalui 2 jalur pemasaran dapat dilihat pada Gambar 3.
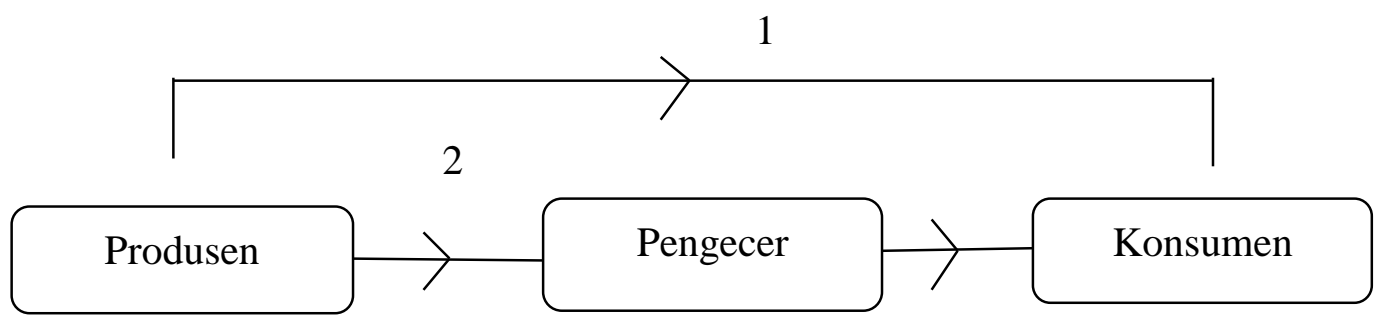

Gambar 3. Saluran Pemasaran Komunitas Lokal Bioversity 
Jalur pertama, konsumen membeli langsung keprodusen teh herbal asam gelugur. Produsen teh herbal asam gelugur menjual produk ditempat mereka memproduksi dikarenakan Komunitas Lokal Bioversity belum memiliki toko sendiri selain ini selain itu juga menerima pesanan melalui sosial media yaitu melalui garciteablogpot.com. Kebaikan dari saluran pemasaran yang pendek ini yaitu cepat mengetahui keinginan konsumen, pengawasan barang lebih muda, dan biaya penyampain lebih kecil sehingga laba lebih tinggi. Dan kelemahan dari saluran pendek ini yaitu keuangan sulit diterima karena menunggu konsumen.

Jalur kedua, produsen menjual kepengecer yang diteruskan ke konsumen. Pengecer menjual teh herbal asam gelugur seperti di mini market dan warung. Kalau di daerah Sijunjung teh herbal asam gelugur ini bisa didapatkan di citra swalayan dan kalamai urang awak. Teh herbal asam gelugur ini telah dipasarkan di luar daerah Sijunjung seperti di Medan, Riau, Jawa, Bali, Bengkulu, Lampung, Kalimantan. Kebaikannya keungangan cenderung cepat diterima karena pasar lebih luas. Kelemahan saluran pemasaran panjang tidak cepat mengetahui keinginan konsumen, pengawasan barang sulit, biaya penyampaian relatif sulit.

Jalur pemasaran yang pertama yang dilakukan oleh Komunitas Lokal Bioversity termasuk kedalam jalur pemasaran langsung sedangkan untuk jalur pemasaran yang kedua temasuk kedalam jalur pemasaran semi langsung hal ini sesui dengan pendapat Soekartawi (1989) yang mengatakan bahawa jalur pemasaran langsung adalah produsen berhadapan langsung dengan konsumen dan melakukan transaksi jual beli. Sedangkan jalur pemasaran semi langsung adalah Pada jalur ini sudah terlihat pedagang pengecer yang bertindak sebagai penghubung antara produsen dengan konsumen.

Panjang pendeknya saluran pemasaran akan mempengaruhi tinggi rendahnya margin pemasaran. Semakin panjang pemasaran maka semakin banyak lembaga pemasaran yang akan terlibat dalam mengambil keuntungan dari fungsi pemasaran yang dilakukan menyebabkan semakin tinggi harga yang akan ditanggung oleh konsumen akhir.

\section{b. Lokasi}

Pemilihan lokasi merupakan faktor penting yang berpengaruh terhadap kesuksesan suatu usaha, karena pemilihan lokasi juga berhubungan dengan keputusan pembelian konsumen. Lokasi yang paling ideal bagi perusahaan adalah lokasi dimana biaya operasionalnya paling rendah atau serendah mungkin. Lokasi yang salah akan menyebabkan biaya operasional perusahaan tinggi, sebagai akibatnya tidak akan mampu bersaing, yang pastinya akan menyebabkan kerugian. Oleh karena itu lokasi tempat usaha yang tepat merupakan tuntutan yang mutlak harus dipenuhi oleh setiap perusahan.

Untuk itu dalam proses pemeliharaan lokasi perusahaan pengusaha harus mempertimbangkan keputusannya dengan benar agar tidak menimbulkan kerugian di kemudian hari.

Dalam teori Webber(1933) dasar pemilihan lokasi pabrik sebagai berikut:

a. Market oriented yaitu industri ditempatkan dekat dengan pasar

b. Raw material oriented yaitu industri ditempatkan dekat dengan bahan bakunya

c. Junction oriented yaitu industri ditempatkan dekat persimpangan antara pasar dan bahan mentahnya 
d. Other oriented yaitu industri ditempatkan dekat dengan pelabuhan, jalan raya.

Lokasi Komunitas

Lokal

Bioversity ini terletak di Nagari Latang Kecamatan Lubuk Tarok. Di Nagari Latang sendiri Komunitas Lokal Bioversty berada didekat jalan utama, jalan utama maksudnya disini adalah jalan penghubung antar daerah dan berdekatan dengan pasar tradisional. Untuk bahan baku juga di pasok oleh masyarakat sekitar sehingga memudahkan dalam mencari bahan baku oleh masyarakat sekitar dan mengurangi biaya trasportasi dalam mencari bahan baku. Jika bahan baku tidak cukup maka Komunitas Lokal Bioversity membeli bahan baku ke daerah Kampung Dalam yang jaraknya tidak terlalu jauh dari Komunitas Lokal Bioversity sekitar $5.5 \mathrm{KM}$.

Dari hasil penelitian lokasi Komunitas Lokal Bioversity telah memenuhi kriteria dasar pemilihan lokasi pabrik menurut webber yaitu market oriented, raw material oriented, junction oriented, other oriented. Karena Komunitas Lokal Bioversity yang pertama dekat dengan pasar yaitu pasar tradisional, selain itu jiga dekat dengan bahan baku dan juga dekat dengan jalan utama.

\subsubsection{Promosi}

Pada hakikatnya promosi merupakan suatu bentuk komunikasi pemasaran. Komunikasi pemasaran adalah aktivitas pemasaran yang berusaha untuk menyebarkan informasi, mempengaruhi/membujuk dan atau mengingatkan pasar sasaran atas perusahaan dan produknya agar bersedia menerima, membeli dan loyal pada produk yang ditawarkan perusahaan yang bersangkutan.
Tujuan utama promosi adalah untuk menginformasikan, mempengaruhi dan membujuk serta mengingatkan pelanggan sasaran tentang perusahaan dan bauran pemasarannya.

Komunitas Lokal Bioversity melakukan promosi dengan tujuan agar teh herbal asam gelugur dapat lebih dikenal oleh seluruh masyarakat serta berbagai kalangan. Selain itu untuk menginformasikan kepada masyarakan tentang khasiat dari buah asam gelugur, yang biasanya hanya di gunakan untuk bumbu masakan.

Beberapa bentuk promosi yang dilakuan oleh Komunitas Lokal Bioversity yaitu:

\section{a. Pameran dagang}

$\begin{array}{cccr}\text { Salah satu cara } & \text { dalam } \\ \text { mempromosikan teh herbal } & \text { asam } \\ \text { gelugur yang di produksi } & \text { oleh }\end{array}$ Komunitas Lokal Bioversity yaitu dengan mengikuti acara pameran dagang yang disponsori oleh Pemda seperti Koperindag, Dinas Pertanian salah satunya pameran dagang Jakarta expo, sehingga dapat mengiklankan produk teh herbal asam gelugur ini kepada para pengunjung pameren yang datang. Selain itu untuk di Sijunjung Komunitas Lokal Bioversity jaga mengikuti bazar dan juga ada di acara 17 agustusan karena diacara 17 agustusan bayak orang yang datang jadi Komunitas Lokal Bioversity dapat memperkenalkan produk mereka kepada masyarakat yang datang sehingga masyarakat lebih mengenal produk tersebut.

b. Iklan

Iklan adalah komunikasi non individu dengan jumlah biaya, melalui berbagai media yang dilakukan oleh perusahaan lembaga non laba serata individu-individu (Swatha dan Sukotjo, 
1995) Komunitas Lokal Bioversity tidak melakukan promosi iklan secaran komersial seperti halnya perusahaanperusahaan besar lainnya. Komunitas Lokal Bioversity hanya melakukan promosi secara terselubung yaitu, melalui pendekatan-pendekatan kepada masyarakat sekitar. iklan yang bersifat komersial hanya berupa iklan di sosial media, iklan yang dilakukan melalui sosila media yaitu melalui garciteablogspot.com dan juga melalui facebook pribadi ibu Sas Junita dengan nama akun Sas Junita, selain iklan di sosial media Komunitas Lokal Bioversity ini juga menggunakan brosur untuk mempromosikan produk teh herbal asam gelugur ini. brosur yang berisi tentang teh herbal asam gelugur beserta khasiat yang didapatkan setelah mengkonsumsi teh herbal asam gelugur. Tujuan dari iklan tersebut teh herbal asam gelugur lebih dikenal oleh masyarakat dan masyarakat lebih mengetahui khasiat dari teh herbal asam gelugur sehingga mereka membeli produk teh herbal asam gelugur.

\subsection{Kendala yang Dihadapi dalam Memasarkan Produk}

Dari hasil penelitian yang telah dilakukan di Komunitas Lokal Bioversity diketahui bahwa kendalah yang dihadapi dalam memesarkan teh herbal asam gelugur yaitu:

a. Dilihat dari segi internal

1. Dilihat dari segi produk

Belum tersedianya ukuran kemasan yang sachet sehingga konsumen kesulitan untuk membeli kerena kemasan yang berukuran kotak harganya cukup mahal, selain itu kurangnnya pengetahuan konsumen tentang khasiat yang dimiliki oleh produk teh herbal asam gelugur ini.

2. Dilihat dari segi harga

Harga teh asam gelugur ini cukup mahal dibandingkan produk teh yang lainnya yang berada di pasaran. Sehingga konsumen cenderung lebih memilih teh yang harganya lebih murah.

3. Dilihat dari segi pendistribusian

Kurangnya tenaga kerja untuk mengantar pesannan konsumen yang berada didaerah sekitar.

4. Dilihat dari segi promosi

Produk teh herbal asam gelugur ini belum melakukan iklan secara komersial seperti iklan di televisi, tetapi baru hanya sebatas iklan disosial media saja sehingga produk ini belum terlalu dikenal oleh masyarakat luas

b. Dilihat dari segi keberadaan pesaing

Menurut Komunitas Lokal Bioversity produk mereka belum memiliki pesaing dengan jenis produk yang sama karena produk mereka ini adalah produk yang pertama memproduksi teh herbal yang berbahan dasar daun dan buah asam gelugur, sehingga Komunitas Lokal Bioversity mempunyai peluang yang sangat potensial dalam memasarkan produk teh herbal asam gelugur ini.

\section{KESIMPULAN DAN SARAN}

\section{Kesimpulan}

1. Bauran pemasarn yang dilakukan oleh Komunitas Lokal Bioversity yaitu (a) bauran produk yang diterapkan di Komunitas Lokal Bioversity terdiri dari kualitas, 
desain, merek, dan ukuran (b) bauran harga yaitu penetapan harga, potongan harga, sistem pembayaran (c) bauran distribusi yang diterapkan yaitu saluran

promosi meliputi pameran dagang dan iklan.

2. Kendala yang dihadapi oleh Komunitas Lokal Bioversity dalam memasarkan produk yaitu (a) segi internal, dari segi internal dilihat dari segi produk, harga, disrtibusi dan promosi (b) segi eksternal dilihat dari segi keberadaan pesaing.

\section{Saran}

1. Diharapkan pada komunitas Lokal Bioversity menyediakan produk dengan berbagai ukuran agar konsumen mudah dalam memilih ukuran produk yang dibutuhkan. Dan untuk harga produk teh herbal asam gelugur ini lebih murah lagi sehingga terjangkau oleh masyarakat menenga kebawah. Semoga teh herbal asam gelugur ini bisa di dapatkan di toko-toko terdekat. Serta promosi teh herbal asam gelugu ini lebih banyak lagi sehinnga masyarakat lebih

banyak tahu tentang khasiat teh ini.

2. Komunitas Lokal Bioversity diharapkan dapat mengatasi masala yang dihadapi mulai dari segi produk, harga, distribusi hingga promosi.

\section{DAFTAR PUSTAKA}

Kotler, Phillip. 2002. Manajemen Pemasaran. Terjemahan. Jilid I Edisi Millenium. Jakarta : PT Indeks.

Pemasaran. Jakarta : Erlangga. dan Gery Armstrong. 2008. Prinsip-prinsip Pemasaran , Edisi 12, Jilid 1. Jakarta : Erlangga. dan Kevin Lane Keller. 2012. Prinsip-prinsip Pemasaran, Edisi 13. Jakarta : Erlangga.

Soekartawi. 1989. Prinsip Dasar Ekonomi Pertanian. Penerbit PT. Raja Grafindo Persada. Jakarta.

Stanto, William. 1991. Prinsip-prinsip Pemasran. Erlangga: Jakarta.

Swasta, Basu dan Ibnu Sukotjo. 1995. Pengantar Bisnis Modren, Edisi 3. Yogyakarta : liberty. 